\title{
PEMILIHAN MODA TRANSPORTASI KERETA API MENUJU PELABUHAN BAKAUHENI
}

\author{
Siti Mutmainnah ${ }^{1}$ \\ Magister Teknik Sipil Universitas lampung ${ }^{1}$ \\ Siti.mutamainnah68@gmail.com
}

\begin{tabular}{lll}
\hline Received: (15 Juni 2020) & Accepted: (22 Juli 2020) & Published : (30 Juli 2020) \\
\hline
\end{tabular}

\begin{abstract}
The plan regarding the construction of a railway line to Bakauheni port initiated by the Ministry of Transportation of the Directorate General of Railways is expected to be implemented so as to reduce traffic load on the road. With the plan to build the Bakauheni port train line, it will provide a choice of a new, more competitive mode for people heading to or from Java Island through the Bakauheni port. With this background, this research was conducted with the aim of knowing what factors will affect passengers heading to or from Java Island through the Bakauheni port by looking at passenger characteristics and what factors affect passengers going to / from Java Island through Bakauheni port in the selection. public transportation modes. In this research, the method used is descriptive analytical. This method describes an event and then an analysis will be carried out on the analysis that arises. Based on the research conducted, it was concluded that the categories of respondents who dominated the selection of the planned train service were respondents with the category of high school education level (SMA) / equivalent (33.3\%), other types of work (23.2\%), total income per month IDR 2.5 million - 5 million (24.2\%), and transportation expenses per month IDR 400,000 - 500,000 (21.2\%). The data processing of the questionnaire survey results for ferry passengers shows that the highest choice of planned train service is "Definitely Choose a Train with a Tariff of Rp. 15,000 with a travel time of 0.5 hours faster" (57\%).
\end{abstract}

Keywords: Mode Choice, Railway,Merak, Bakauheni

\begin{abstract}
Abstrak
Rencana mengenai pembangunan jalur kereta api menuju pelabuhan Bakauheni yang diinisisasi oleh Kementerian Perhubungan Direktorat Jenderal Perkeretaapian diharapkan dapat terlaksana sehingga dapat mengurangi pembebanan lalu lintas pada jalan raya. Dengan adanya rencana pembangunan jalur kereta pelabuhan Bakauheni akan memberikan suatu pemilihan moda baru yang lebih kompetitif kepada masyarakat yang menuju atau dari Pulau Jawa melalui pelabuhan Bakauheni. Dengan latar belakang tersebut maka dilakukan penelitian ini dengan tujuan untuk mengetahui faktor apa saja yang akan mempengaruhi penumpang yang menuju atau dari Pulau Jawa melalui pelabuhan Bakauheni dengan melihat Karakteristik penumpang dan faktor apa saja yang mempengaruhi penumpang yang menuju/dari Pulau Jawa melalui pelabuhan Bakauheni dalam pemilihan moda transportasi umum. Dalam penelitian ini metode yang digunakan yaitu deskriptis analitis. Metode ini menggambarkan suatu peristiwa dan selanjutnya akan dilakukan analisis terhadap analisis yang timbul. Berdasarkan penelitian yang dilakukan didapatkan kesimpulan kategori responden yang mendominasi pemilihan pelayanan kereta api rencana tersebut adalah responden dengan kategori tingkat pendidikan Sekolah Menengah Atas (SMA)/Sederajat (33,3\%), jenis pekerjaan Lainnya (23,2 \%), jumlah pendapatan per bulan Rp 2,5 juta - 5 juta (24,2\%), dan pengeluaran biaya transportasi per bulan Rp $400.000-500.000$ $(21,2 \%)$. Pengolahan data hasil survei kuisioner terhadap penumpang kapal ferry menunjukkan bahwa pilihan pelayanan kereta api rencana tertinggi yaitu "Pasti Memilih Kereta Api dengan Tarif Rp 15.000 dengan waktu tempuh lebih cepat 0,5 jam" (57\%).
\end{abstract}

Kata Kunci: pemilihan moda, kereta api, Merak, Bakauheni

To cite this article:

Mutmainnah.(2020) Pemilihan Moda Transportasi Kereta Api Menuju Pelabuhan Bakauheni. Journal Of Infrastructural In Civil Engineering, $\operatorname{Vol}(1), 32-42$ 


\section{PENDAHULUAN}

Transportasi umum penumpang yang paling banyak digunakan saat ini baik dari maupun menuju Pelabuhan penyebrangan bakauheni adalah bus dan travel. Waktu yang dibutuhkan untuk melakukan perjalanan dari Bakauheni hingga Bandar Lampung kurang lebih selama 3,5 jam jika perjalanan dilakukan melalui jalur non tol. Transportasi umum tersebut belum memiliki jadwal keberangkatan dan kedatangan yang pasti.

Penumpang yang akan melakukan perjalanan ke Pelabuhan Bakauheni dapat menggunakan jasa Travel Rute Rajabasa - Bakauheni dengan memesan tiket via telepon atau bisa memesannya langsung di Po. Bus atau memesan di terminal. Selain memesan tiket secara langsung, penumpang juga dapat secara langsung memberhentikan transportasi umum tersebut saat melintas di trayek tersebut.

Lamanya waktu tempuh perjalanan dipengaruhi oleh tingkat keterisian tempat duduk. Jika kendaraan telah terisi penuh maka waktu tempuhnya cepat sedangkan jika kendaraan baru terisi setengah atau tiga per empat maka akan membutuhkan waktu perjalanan lebih lama karena menunggu tempat duduk terisi penuh. Waktu tempuh yang tidak menentu khususnya waktu yang lama sehingga penumpang merasa kurang nyaman. Tidak hanya itu kondisi armada yang tidak seluruhnya dalam kondisi baik, sikap pengemudi yang tidak memperhatikan keselamatan serta adanya sistem percaloan penumpang membuat perjalanan penumpang semakin tidak nyaman.

Survei yang dilakukan oleh Balitbanghub mengenai asal tujuan transportasi tahun 2011 menunjukkan bahwa pola perjalanan penumpang di Provinsi Lampung didominasi pergerakan menuju/dari Provinsi Sumatera Selatan menuju ke Pulau Jawa khususnya Provinsi Banten, Provinsi Jawa Barat dan Provinsi DKI Jakarta sebesar 88.348.092 orang pertahun. Demikian juga dengan pola perjalanan barang paling banyak yaitu pergerakan menuju/dari Provinsi Sumatera Selatan menuju ke Pulau Jawa khususnya Provinsi Banten, Provinsi Jawa Barat dan Provinsi DKI Jakarta sebesar 176.068.593 ton pertahun

(Fathoni dan Priyanto, 2005) melakukan penelitian dengan judul Estimasi Matriks Asal dan Tujuan Perjalanan Penumpang Angkutan Umum Trans Jawa-Sumatera Melalui Lintasan Penyeberangan MerakBakauheni mendapatkan hasil bahwa proporsi perjalanan antar zona DKI Jakarta dan Lampung sebesar 2.728.111 orang penumpang per tahun, zona Sumatera Selatan dan DKI Jakarta sebanyak 1.255.835 orang penumpang per tahun, zona Sumatera Utara dan DKI Jakarta sebesar 782.165 orang penumpang per tahun, dan zona Sumatera Barat dan DKI Jakarta sebesar 602.537 penumpang per tahun

(Aryantono, 2008) memperkirakan trend pertumbuhan jumlah penumpang dan barang dengan tahap 5 tahunan pada lintas Bakauheni-Merak dan Merak-Bakauheni, dimana tahun dasarnya digunakan tahun 2005, diperoleh nilai rata-rata pertumbuhan 6,9 \% per tahun (4.551.210 penumpang) untuk lintas Bakauheni-Merak. Sementara pada lintas Merak-Bakauheni diperoleh nilai rata-rata pertumbuhan 5,11\% per tahun (4.488.296 penumpang). Pada kurun waktu 2010 sebesar 4\% per tahun (lintas Bakauheni-Merak sebesar 5.537.243 dan Merak-Bakauheni 5.460.698) dan 3\% per tahun pada kurun waktu 2015-2025 (lintas Bakauheni-Merak sebesar 6.419.183 dan Merak- Bakauheni 6.330.446 untuk tahun 2015, serta lintas Bakauheni-Merak sebesar 8.626.845 dan Merak-Bakauheni 8.507.590 untuk tahun 2025).

Penelitian (Sulistiyorini, 2015) menunjukkan bahwa adanya pola pergerakan orang diruas jalan di Provinsi Lampung dari provinsi Sumatera Selatan ke Pulau Jawa atau sebaliknya cukup besar. Jumlah pergerakan orang pada tahun 2014 berjumlah 8 juta penumpang pertahun. Pergerakan lainnya yaitu dari Bengkulu ke Pulau Jawa dan sebaliknya dengan jumlah 0,7 juta penumpang pertahun. Angka ini menunjukkan banyaknya pergerakan berupa pergerakan lalu lintas menerus dan pola tersebut akan serupa dalam tahun selanjutnya. Diperkirakan pergerakan inii sampai tahun 2035 akan mencapai 43 juta penumpang dengan 3,8 juta penumpang per tahun.

Rencana mengenai pembangunan jalur kereta api menuju pelabuhan Bakauheni yang diinisisasi oleh Kementerian Perhubungan Direktorat Jenderal Perkeretaapian diharapkan dapat terlaksana sehingga dapat mengurangi pembebanan lalu lintas pada jalan raya. Dengan adanya rencana pembangunan jalur kereta pelabuhan Bakauheni akan memberikan suatu pemilihan moda baru yang lebih kompetitif kepada masyarakat yang menuju atau dari Pulau Jawa melalui pelabuhan Bakauheni.

Dengan latar belakang tersebut maka dilakukan penelitian ini dengan tujuan untuk mengetahui faktor apa saja yang akan mempengaruhi penumpang yang menuju atau dari Pulau Jawa melalui pelabuhan Bakauheni 
dengan melihat Karakteristik penumpang dan factor apa saja yang mempengaruhi penumpang yang menuju/dari Pulau Jawa melalui pelabuhan Bakauheni dalam pemilihan moda transportasi umum.

\section{METODE PENELITIAN}

Sebelum melakukan analisis data perlu dilakukan pengumpulan data. Data yang dikumpulkan merupakan data primer dan data sekunder. Pengumpulan data sekunder diperoleh dari data survei di lapangan dengan membagikan kuisioner. Dalam pengisisan kuisioner responden dipandu oleh surveyor. Surveyor dapat membacakan pertanyaan dan memberi penjelasan mengenai pertanyaan yang ada pada kuisioner. Banyaknya sampel diambil berdasarkan ukuran populasi dan batas taraf signifikansiketepatannya. Taraf signifikansi menjelaskan adanya penyimpangan pada hasil, apabila taraf signifikansi ketepatan $1 \%$ maka kekeliruan mewakili populasi hanya $1 \%$. Taraf signifikansi ini digunakan pada penelitian ini adalah $10 \%$.

Jumlah sampel yang akan diambil adalah sebanyak 100 sampel. Substansi pertanyaan pada formulir wawancara yang dibagikan kepada responden mencakup profil respondedn, karakteristik perjalanan dan persepsi responden dengan rincian sebagai berikut:

1. Profil Responden
a. Usia
b. Jenis kelamin
c. Tempat asal perjalanan
d. Tingkat pendidikan
e. Jenis pekerjaan
f. Pendapatan rata-rata per bulan

2. Karakteristik Perjalanan

a. Maksud perjalanan

b. Frekuensi perjalanan dalam 1 tahun terakhir

c. Alternatif pilihan moda transportasi darat eksisting yang digunakan untuk menuju/dari pelabuhan Bakauheni

Dalam penelitian ini metode yang digunakan yaitu deskriptis analitis. Metode ini menggambarkan suatu peristiwa dan selanjutnya akan dilakukan analisis terhadap analisis yang timbul. Setelah mendapatkan data dari kuisioner yang diberikan kepada penumpang maka akan diperoleh data karakteristik penumpang dan minat penumpang terhadap moda transportasi yang direncanakan.

\section{HASIL DAN PEMBAHASAN}

Pengambilan data dilakukan dengan melakukan perjalanan dari Bakauheni-Merak dan Merak-Bakauhen pada hari Sabtu tanggal 26 Oktober 2019 dan Minggu tanggal 27 Oktober 2019 pada pukul $08.00-20.00$ WIB.

Data yang didapat dari PT. ASDP menunjukan tren pertumbuhan penumpang di Pelabuhan merak dan Bakauheni dimana terdapat peningkatan hingga mencapai 3\% per tahun. (indonesiaferry.co.id. 2017) Tahun 2016 terdapat 1,55 juta orang melakukan perjalanan dari Merak menuju Bakauheni. Angka ini naik 21\% dibandingkan tahun 2015 sebanyak 1,28 juta orang.

Dalam penelitian ini data sekunder merupakam data dari data pertumbuhan kendaraan dan ruas jalan di Provinsi Lampung. Data sekunder lainnya adalah pertumbuhan penumpang di pelabuhan Merak dan Bakauheni. Tabel 1 menunjukkan data mengenai pertumbuhan kendaraan bermotor di Provinsi Lampung dan juga pertumbuhan penanganan jalan. Sedangkan Tabel 2. Menunjukkan pertumbuhan panjang jalan 


\begin{tabular}{ccc}
\hline No. & Jumlah Kendaraan (Kendaraan) & Tahun \\
\hline 1. & 3.087 .919 & 2016 \\
2. & 3.235 .200 & 2017 \\
3. & 3.389 .527 & 2018 \\
\hline
\end{tabular}

Sumber : Provinsi Lampung dalam Angka, Badan Pusat Statistik Provinsi Lampung . 2019.

\begin{tabular}{lcc}
\hline No. & Panjang Jalan $(\mathrm{Km})$ & Tahun \\
\hline 1. & 2.985 .483 & 2017 \\
2. & 1.693 .273 & 2018 \\
\hline
\end{tabular}

Sumber : Provinsi Lampung dalam Angka, Badan Pusat Statistik Provinsi Lampung . 2019.

Data primer yang didapat merupakan data yang didapatkan melalui proses pengisian kuisioner yang dilakukan dalam kapal penumpang penyeberangan pelabuhan Bakauheni-Merak oleh responden. Didapatkan 150 kuisioner yang telah diisi oleh responden. Namun hanya 100 kuisioner (sampel) yang datanya akan dianalisis lebih lanjut.

Data-data yang didapatkan dari responden diantaranya data profil responden yaitu mengenai usia, alamat asal dan tujuan. Selain profil responden didapat juga data karakteristik penumpang yang meliputi pekerjaan, maksud perjalanan, moda transportasi yang digunakan dan intensitas melakukan perjalanan.

Berdasarkan hasil dari penyebaran kuisioner terhadap penumpang kapal ferry di pelabuhan BakauheniMerak. Pada karakteristik usia terdapat empat kelompok usia dengan masing masing penumpang dengan rincian terhadap 17-20 tahun sebanyak 4\%, 21-25 tahun sebanyak 57\%, 36-50 tahun sebanyak 29\% dan lebih dari 50 tahun sebanyak 10\%. Penumpang paling banyak berada di kategori usia 21-35 tahun

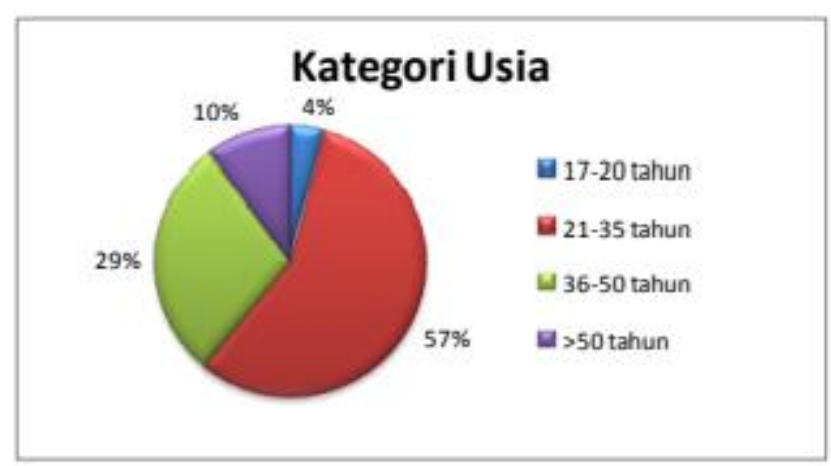

Gambar 1. Karakteristik Usia

Hasil survey penumpang kapal ferry pelabuhan Bakauheni-Merak menunjukkan presentase responden berdasarkan jenis kelamin ditnjukkan pada Gambar 2. Data menunjukkan penumpang pria lebih banyak daripada wanita dimana penumpang pria sebanya $85 \%$ sedangkan wanita hanya $15 \%$ 


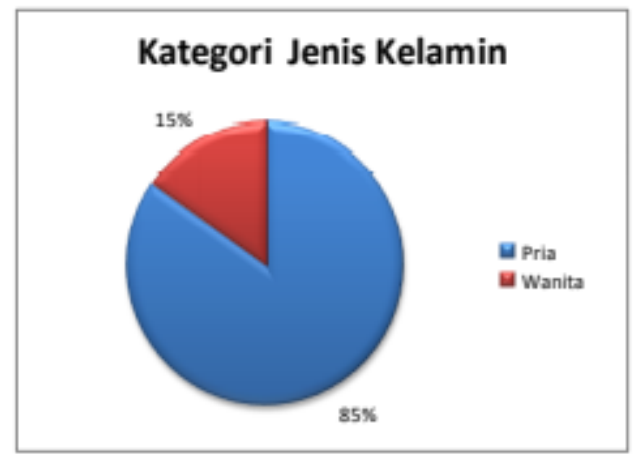

Gambar 2. Karakteristik Usia

Berdasarkan hasil survei dari penyebaran kuisioner terhadap penumpang kapal ferry pelabuhan Bakauheni-Merak untuk karakteristik pendidikan terakhir didapatkan data terbesar dari karakteristik tingkat Pendidikan adalah pendidikan Sekolah Menengah Atas (SMA)/sederajat yaitu sebesar 52\%. Hasil perbandingan persentase berdasarkan kategori pendidikan terakhir ditunjukkan pada Gambar 3

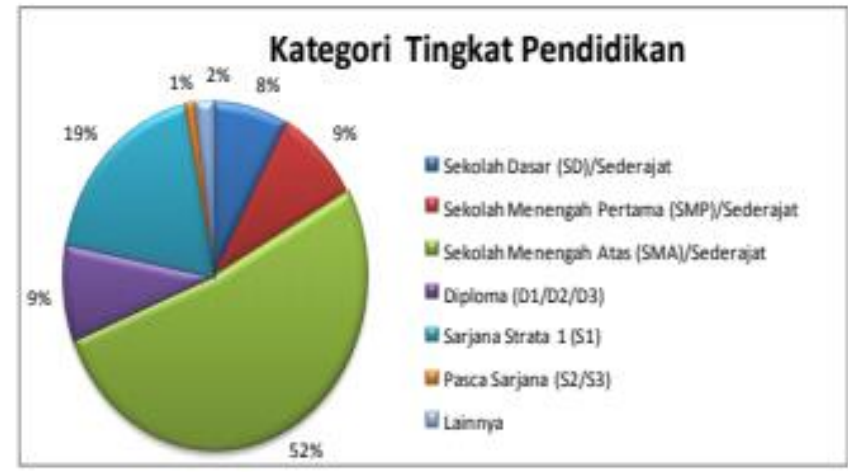

Gambar 3. Karakteristik Tingkat Pendidikan

Hasil survei penyebaran kuisioner yang dilakukan terhadap penumpang di kapal ferry pelabuhan Bakauheni-Merak untuk karakteristik jenis pekerjaan didapatkan responden terbesar yaitu responden dengan pekerjaan pengusaha/wiraswasta sebesar 32\%. Rincian presentasi hasil kuisioner karakteristik pekerjaan ditunjukkan pada Gambar 4.

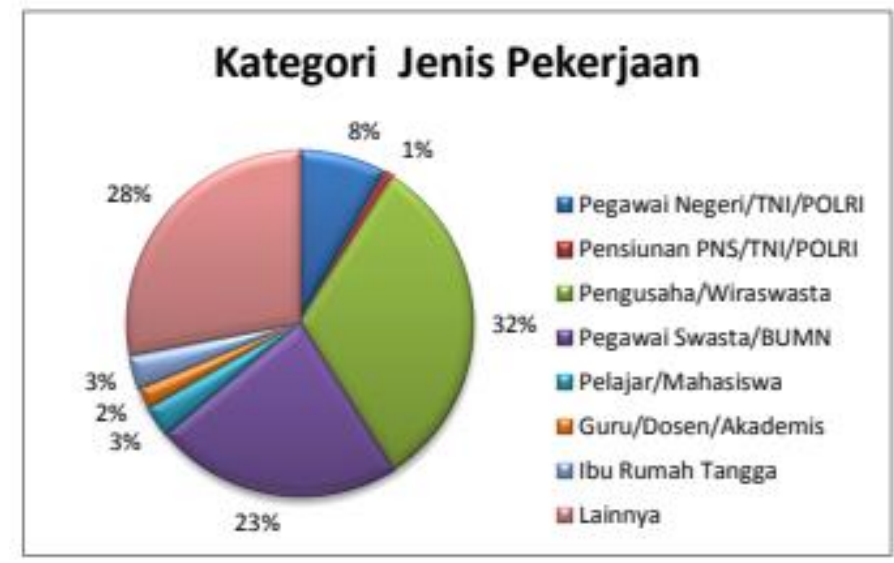

Gambar 4. Karakteristik Jenis Pekerjaan 
Karakteristik yang lainnya adala pendapatan per bulan. Hasil survei penyebaran kuisioner terhadap penumpang kapal ferry pelabuhan Bakauheni-Merak menunjukkan bahwa karakteristik pendapatan per bulan yang didapatkan responden terbesar adalah responden dengan pendapatan per bulan 2,5 - 5 Juta Rupiah dengan presentase $43 \%$. Presentase karakteristik pendapatan per bulan lainnya ditunjukkan pada gambar 5 .

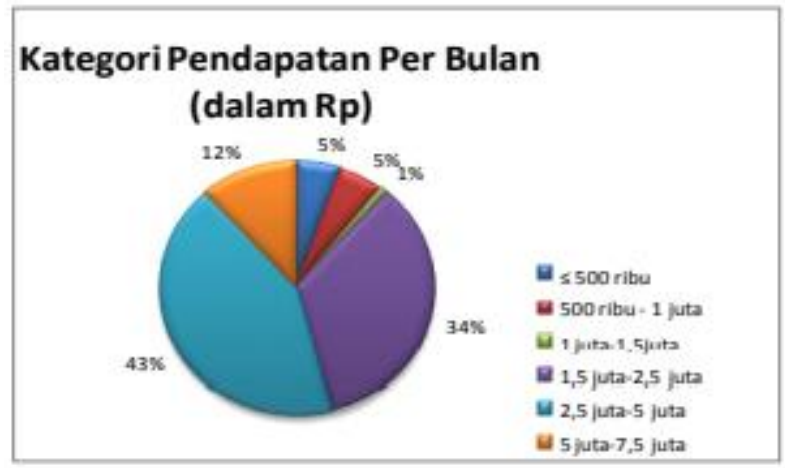

Gambar 5. Karakteristik Pendapatan Per Bulan

Berdasarkan kuisioner didapatkan frekuensi perjalanan oleh responden. Frekuensi yang dimaksud adalah frekuensi perjalanan responden dalam satu tahun. Frekuensi perjalanan terbesar adalah responden dengan jumlah perjalanan sebanyak 8-12 kali dengan presentase sebesar 33\%. Presentase lainnya dari frekuensi perjalanan dapat diliha pada gambar 6 .

Hasil lainnya yang didapat dari survey yang dilakukan oleh responden yang ada di kapal ferry MerakBakauheni adalah maksud perjalanan responden. Maksud perjalanan responden yang paling banyak adalah perjalanan dengan maksud perjalanan bisnis/pekerjaan/berdagang dengan presentasi yaitu sebesar $43 \%$ disusul dengan maksud tujuan lain-lain dengan presentasi 39\%. Data mengenai maksud perjalanan responden ditunjukkan pada Gambar 7.

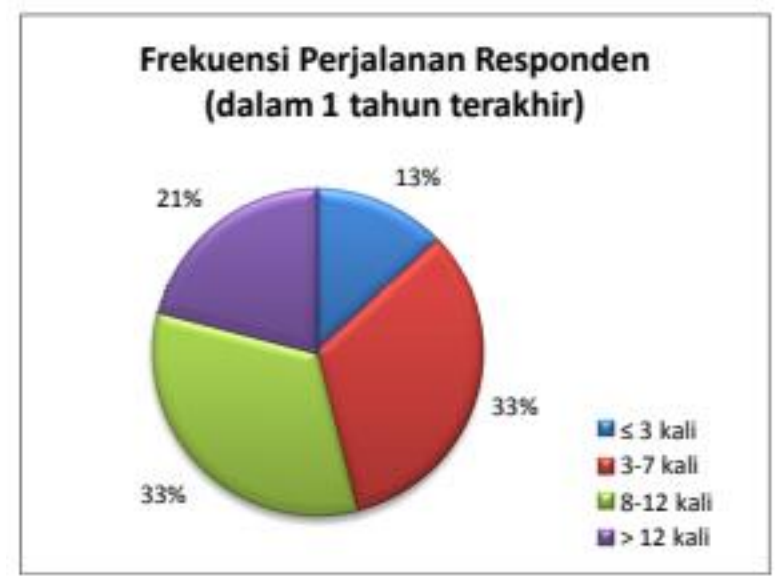

Gambar 6. Frekuensi Perjalanan 


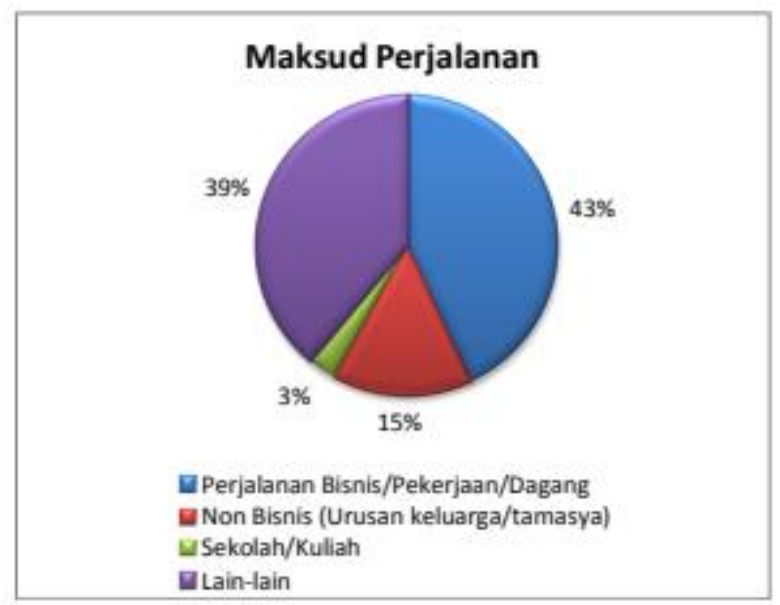

Gambar 7. Maksud Perjalanan

Hasil survey yang dilakukan kepada responden juga memberikan data mengenai karakteristik biaya transportasi sebulan. Perjalanan dengan presentase biaya transportasi terbesar adalah responden yang mengeluarkan biaya transportasi sebesar Rp 400.000- Rp 500.000 per bulan yaitu sebesar $32 \%$.

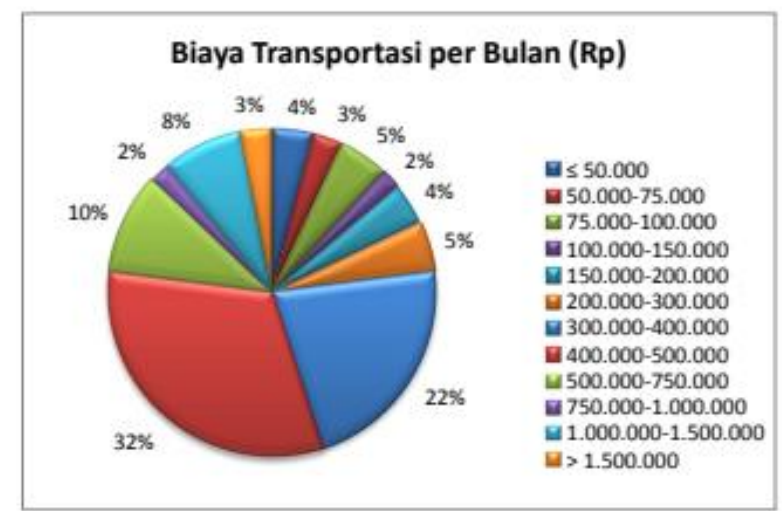

Gambar 8. Karakteristik Baiaya Transportasi per Bulan

Selain karakteristik perilaku perjalanan oleh penumpang kapal ferry Merak-Bakauheni. Responden juga memberikan tanggapan mengenai pemilihan moda kereta api. Banyaknya responden yang memilih kondisi pelayanan kereta api rencana dapat dilihat pada gambar berikut: 


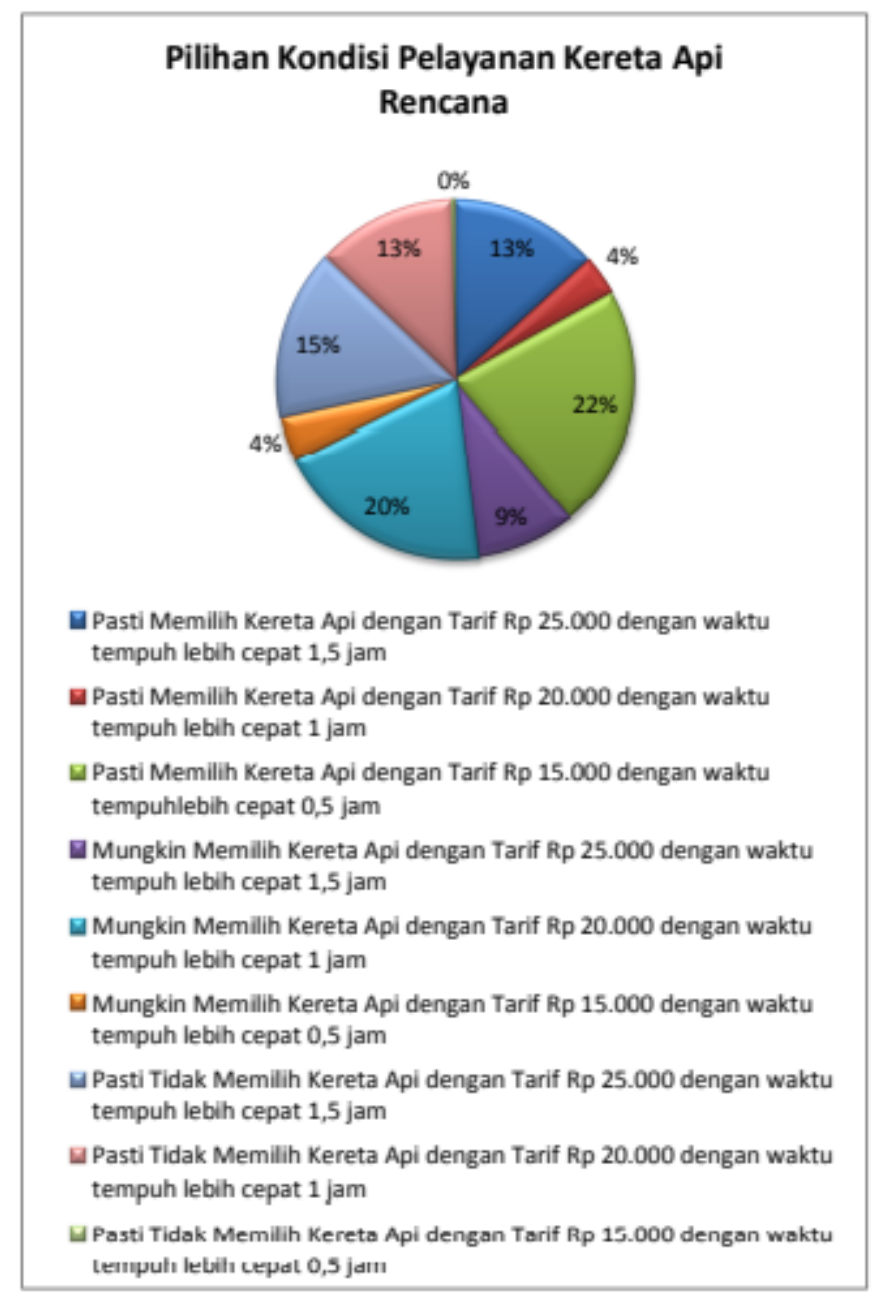

Gambar 9. Pilihan Kondisi Pelayanan Kereta Api Rencana

Berdasarkan hasil survey yang ditunjukkan pada gambar dapat disimpulan bahwa minat responden terbesar (22\%) pada pelayanan kereta api rencana dengan tarif sebesar Rp 15.000 dengan waktu tempuh lebih cepat $0,5 \mathrm{jam}( \pm 3$ jam).

Untuk memastikan seluruh item pernyataan yang digunakan pada penelitian ini mempunyai konsistensi internal dalam mengukur aspek yang sama dalam kuisioner dalam penelitian ini dilakukan uji yaitu uji validitas dan uji reliabilitas. Uji validitas (keabsahan) dan reliabilitas (keandalan) dari alat ukur yang digunakan dalam dapat diketahui dari data kuisioner yang diperoleh melalui atribut perubahan pada moda transportasi dan nilai-nilai yang diharapkan. Analisis uji validitas yang telah dilakukan menunjukkan bahwa seluruh item pertanyaan dalam penelitian ini adalah valid.

Uji dilakukan untuk mencari nilai r tabel Pearson's Product Moment . Apabila nilai Pearson's Product Moment diketahui signifikansi untuk $\alpha=5 \%(0,05)$ dan $\mathrm{df}=(\mathrm{N}-2)$ dimana nilai $\mathrm{N}$ adalah jumlah responden sebanyak 100 dikurangi 2 maka didapatkan $\mathrm{df}=98$, maka $\mathrm{r}$ tabel $=0,1978$. Pada jumlah responden didapatkan sebanyak 100 responden dengan 5 soal.

Hasil uji reliabilitas yang telah dilakukan menunjukkan bahwa nilai Alpha Cronbach $(\alpha)$ antara 0,70 - 0,90 dengan nilai 0,82 sehingga dapat disimpulkan bahwa hasil pengujian reliabilitas tinggi untuk dilakukan analisis lebih lanjut. 
Analisis data dilakukan untuk menggambarkan jumlah persentase pilihan responden terhadap pelayanan kereta api rencana. Digunakan sekenario data responden dengan pilihan "pasti memilih", karena responden tersebut diasumsikan pasti akan menggunakan pelayanan kereta api rencana bila beroperasi.

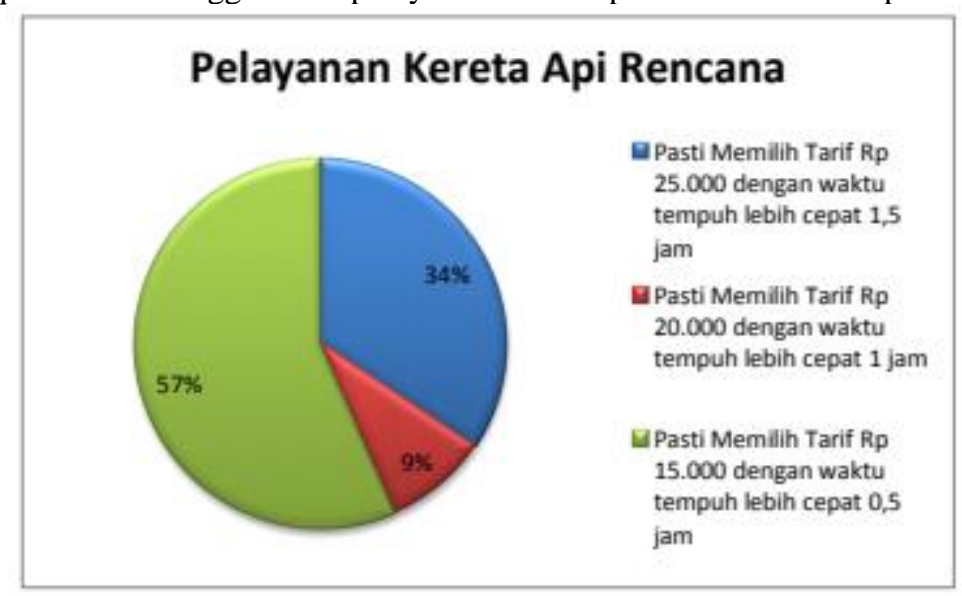

Gambar 10. Minat Pelayana Kereta Api Rencana

Hasil kuisioner menunjukkan bahwa responden dengan pilihan pelayanan kereta api rencana "Pasti Memilih Tarif Rp 15.000 dengan waktu tempuh lebih cepat 0,5 jam" dipilih paling banyak dengan presentase sebesar $57 \%$. Dari data yang telah didapatkan juga terlihat bahwa minat penumpang terbesar terhadap kereta api rencana bila tarif pelayanannya murah meskipun waktu tempuhnya lama ( \pm 3 jam).

\section{SIMPULAN}

Berdasarkan hasil pengujian Chi-square dengan uji Cramer's V bahwa faktor karakteristik pengguna kendaraan (responden) yang mempengaruhi pemilihan moda transportasi yaitu tingkat pendidikan, jenis pekerjaan, jumlah pendapatan dan pengeluaran biaya transportasi per bulan. Kategori responden yang mendominasi pemilihan pelayanan kereta api rencana tersebut adalah responden dengan kategori tingkat pendidikan Sekolah Menengah Atas (SMA)/Sederajat (33,3\%), jenis pekerjaan Lainnya (23,2 \%), jumlah pendapatan per bulan Rp 2,5 juta -5 juta $(24,2 \%)$, dan pengeluaran biaya transportasi per bulan Rp $400.000-500.000(21,2 \%)$.

Pengolahan data hasil survei kuisioner terhadap penumpang kapal ferry pelabuhan Bakauheni menggunakan sekenario "pasti memilih". Hal ini karena responden tersebut diasumsikan pasti akan menggunakan pelayanan kereta api rencana bila beroperasi. Dari data tersebut diketahui bahwa pilihan pelayanan kereta api rencana tertinggi yaitu "Pasti Memilih Kereta Api dengan Tarif Rp 15.000 dengan waktu tempuh lebih cepat 0,5 jam" (57\%).

\section{DAFTAR PUSTAKA}

ASDP Indonesia Ferry. Beroperasi 2018, PT.ASDP Kembangkan Dermaga Eksekutif Merak-Bakauheni. 23 Mei 2017. indonesiaferry.co.id/siaran.pers. Diakses pada 13 Oktober 2019

Aryantono, Nanang. 2008. Skenario Peningkatan Kelancaran Pergerakan Orang Maupun Barang Yang Efektif dan Efisien Pada Lintas Penyeberangan Merak-Bakauheni. Badan Penelitian dan Pengembangan, Departemen Perhubungan. Warta Penelitian Perhubungan, Volume 20 Nomor 7, 2008.

Fathoni, Muhammad dan Priyanto, Sigit. 2005. Estimasi Matriks Asal dan Tujuan Perjalanan Penumpang Angkutan Umum Trans Jawa-Sumatera Melalui Lintasan Penyeberangan Merak-Bakauheni. Lalu Lintas Angkutan Sungai, Danau dan Penyeberangan (LLASDP), Sekolah Tinggi Transportasi Darat (STTD). Makalah Konferensi Forum Studi Transportasi Antara Perguruan Tinggi (FSTPT) VIII, Desember 2005. 
Sulistyorini, Rahayu., Herianto, Dwi dan Gaol, Intan Bonita Lumban. 2015. Analisis Kinerja Jaringan Jalan di Provinsi Lampung dengan Menggunakan Permodelan Transportasi. Jurusan Teknik Sipil, Fakultas Teknik, Universitas Lampung. Jurnal Rekayasa, Vol.19, No.3, Desember 2015, halaman 191-204. 